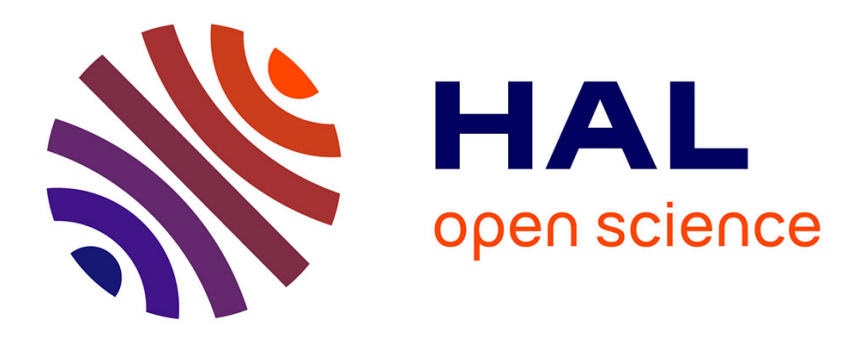

\title{
The Effect of the Euro on Aeronautic Trade: A French Regional Analysis
}

Fabien Candau, Serge Rey

\section{To cite this version:}

Fabien Candau, Serge Rey. The Effect of the Euro on Aeronautic Trade: A French Regional Analysis. Economic Modelling, 2014, 41, pp.345-355. hal-01844378

\section{HAL Id: hal-01844378 https: / hal-univ-pau.archives-ouvertes.fr/hal-01844378}

Submitted on 2 Apr 2019

HAL is a multi-disciplinary open access archive for the deposit and dissemination of scientific research documents, whether they are published or not. The documents may come from teaching and research institutions in France or abroad, or from public or private research centers.
L'archive ouverte pluridisciplinaire HAL, est destinée au dépôt et à la diffusion de documents scientifiques de niveau recherche, publiés ou non, émanant des établissements d'enseignement et de recherche français ou étrangers, des laboratoires publics ou privés. 


\title{
The effect of the euro on aeronautic trade: A French regional analysis
}

\author{
Fabien Candau*, Serge Rey
}

CATT, Univ Pau E Pays Adour, France

\section{A R T I C L E I N F O}

\section{Article history:}

Accepted 12 May 2014

Available online 18 June 2014

\section{Keywords:}

French regional clusters

Aerospace industry

Aeronautic trade

Gravity model

\begin{abstract}
A B S T R A C T
After describing the spatial distribution of the aeronautic industry in France, this study analyzes the determinants of French regional bilateral exports and imports, according to a trade gravity model, for the period 2003-2010. The appreciation of the euro has a negative impact on exports and a positive effect on imports, confirming the fears of European politicians and managers in the aeronautic sector. The gravity equation, extended to integrate factor complementarities among partners, also shows that labor productivity levels in France and its partner countries are significant determinants of trade, supporting O-ring theory applied from Kremer (1993) to explicate trade in the aeronautical sector. The spatial organization of this sector is also analyzed via the impact of foreign military spending on French trade. Finally, by distinguishing French imports and arrivals of products manufactured in Europe and in France, supplementary estimations reveal that outward foreign direct investment FDI affects the imports and arrivals of European products negatively but has positive influences on the imports and arrivals of French products.
\end{abstract}

c) 2014 Elsevier B.V. All rights reserved.

\section{Introduction}

Historically, France has been a major player in the aerospace industry. At the end of World War I, France led aircraft production; only in 1930 did the United States start to acquire a dominant position, which it strengthened after World War II. In the 1960s, France allied with the United Kingdom to complete the Concorde project; in 1970, it coordinated with Germany on the Aerospatiale, to be joined by CASA Spanish in 1971 and British Aerospace in 1979. As a result of this process of mergers and acquisitions, the European Aeronautic Defense and Space (EADS) company was founded in 2000, to become the Airbus group on January 1, 2014. As Table 1 shows, France ranks second in the world as an exporter of aircraft and spacecraft, and Airbus is the second most important firm in the defense and aerospace sector.

The aerospace industry (aeronautics and space) has a critical importance in France. Indeed, this sector accounts for nearly $4 \%$ of total industrial employment and fosters various indirect jobs in related sectors. It is also one of the few industrial sectors to have at least maintained employment levels throughout the 2000s. Moreover, since the end of the 1990s, France has suffered a deterioration of its trade balance; the trade deficit of 231 million euros in 2003 increased to 24 billion euros in 2005 and 70 billion euros by 2011. Few sectors have resisted this troubling trend, such as luxury, pharmaceuticals, and aerospace. As Fig. 1 shows, despite a wealth of economic crises over the past four decades, the trade balance in the aerospace industry has remained positive, with a growing surplus.

\footnotetext{
* Corresponding author at: Department of Economics, C.A.T.T., University of Pau et Pays de l'Adour, Avenue du Doyen Poplawski, B.P. 1633, 64016 Pau Cedex, France.

E-mail addresses: fabien.candau@univ-pau.fr (F. Candau), serge.rey@univ-pau.fr (S. Rey).
}

Furthermore, amounting to 2546 million euros in 2009, R\&D expenditures by French aerospace firms represent 10\% of the internal R\&D expenditures of French enterprises-the third most substantial, after automobile and pharmaceutical sectors. For aerospace companies during the 2000s, these expenses accounted for around $18 \%$ of their total turnover. Furthermore, self-financed R\&D represents $54 \%$ of global R\&D (the remaining $46 \%$ comes mainly from public funding; ECORYS, 2009).

Lastly, France seeks to integrate its regional aerospace sector in regional policies (see Schönfeld and Jouaillec, 2008, p. 1). As of July 2005, 67 clusters, covering most industrial sectors, were approved by the French government. The aeronautic and space industry was represented primarily in three clusters, located according to the industry's historical regionalization: ASTech Paris in Ile-de-France, Aerospace Valley spanning the Aquitaine and Midi-Pyrénées regions, and Pégase in Provence-Alpes-Côte-d'Azur.

Considering that the aerospace sector thus constitutes one of the main pillars of French industry, it is easy to understand why French authorities became worried when the euro appreciated strongly against the U.S. dollar. Competition also is increasing in the aeronautic industry. Take the 100-plus seat jetliner category as an example. Products such as Boeing's 737 or Airbus' A320 confront increasing horizontal and vertical competition, all around the world, ${ }^{1}$ which is not limited to Airbus and

\footnotetext{
1 In addition to traditional competitors, such as Brazil's Embraer and its E-Jets (E190 and E195), likely market entrants include Japan's Mitsubishi (MRJ-90), with a maiden flight scheduled for 2014; the Commercial Aircraft Corporation of China, whose C919 plane, seating 168-190, is scheduled for 2016; and the Russian company Irkut, with its MS-21 designed for 150 passengers. We also include on this list the Canadian firm Bombardier, which plans to deliver its CSseries, with 110 and 130 seats, in 2014.
} 
Table 1

Firms and exporters in the aerospace sector.

\begin{tabular}{lll}
\hline Rank & $\begin{array}{l}\text { Aircraft and spacecraft exporters } \\
\text { (US\$ billion and world share) }\end{array}$ & $\begin{array}{l}\text { Top defense and aerospace companies } \\
\text { (revenue in the first half of 2013) }\end{array}$ \\
\hline 1 & USA: $\$ 104.3$ bn $(30 \%)$ & Boeing: $\$ 40.7$ bn \\
2 & France: $\$ 54.5$ bn $(19.3 \%)$ & EADS, Europe: $\$ 34.25$ bn \\
3 & Germany: $\$ 43.4$ bn $(15.4 \%)$ & United Techno. Corp.: $\$ 30.40$ bn \\
4 & UK: $\$ 16.7$ bn $(5.9 \%)$ & Lockheed Martin: $\$ 22.47$ bn \\
5 & Canada: $\$ 10.3$ bn $(3.6 \%)$ & General Dynamics Corp.: $\$ 15.31$ bn \\
6 & Singapore: $\$ 6.0$ bn $(2.1 \%)$ & Northrop Grumman: $\$ 12.39$ bn \\
7 & Italy: $\$ 5.7$ bn $(2.0 \%)$ & BAE System, UK: $\$ 12.09$ bn \\
8 & Brazil: $\$ 5.2$ bn $(1.9 \%)$ & Raytheon: $\$ 11.99$ bn \\
9 & Spain: $\$ 4.5$ bn $(1.6 \%)$ & Finmeccanica, Italy: $\$ 10.43$ bn \\
10 & Japan: $\$ 3.9$ bn $(1.4 \%)$ & GE Aviation: $\$ 10.37$ bn \\
\hline
\end{tabular}

Source: ECORYS (2009) and http://www.army-technology.com/features/feature-highestearning-defence-and-aerospace-companies/, November 2013.

a Companies are based in the United States, unless otherwise indicated.

b The company expects to generate full-year revenues of \$83-\$86 bn in 2013.

Boeing but involves the entire aeronautic industry. European politicians thus complain loudly about the barriers to export and international competition, such as when former French President Nicolas Sarkozy worried, in June 2008, "Every time that the euro appreciates by ten cents, Airbus lose one billion euros! We cannot be competitive against Boeing who sells in dollars, if the euro is $30 \%$ over-valued."

Airbus already has responded to this challenge, by relocating part of its production and R\&D. In 2008 the company began to assemble its A320 in Tianjin, China. Starting in summer 2013, Airbus initiated the construction of assembly lines for the A319, A320, and A321 in the town of Mobile, Alabama (USA); aircraft assembly is slated to start in 2015. With this study, we aim to determine whether these observations are merely anecdotal or if the euro effectively has influenced the French aeronautical industry.

We propose to analyze the evolution of the aircraft industry in France, using a trade-based approach at the French regional level. Thus, we attempt to determine precisely how producers have been affected by worldwide competition and the appreciation of the euro. Moreover, this article deals with the coordination and organization of trade in the aeronautic sector in accordance with O-ring theory. In the aerospace sector, where a simple O-ring was the cause of the tragic crash of the space shuttle Challenger, Kremer (1993) asserts that the value of a product depends on the value of its cheapest components. By extending a standard gravity equation, we show that labor productivities in France and its partner countries are significant determinants of trade, in support of the view that complementarities matter. In addition, using military spending as a measure of local and specific knowledge in each country, we interpret their positive impacts on export as an indication that trade may be driven by the unbundling of the production process (Baldwin, 2006), with complementarities across locations. Because French exports increase with military spending, network effects appear to overtake any home bias (i.e., discriminatory public procurement), which in turn implies that production processes take place in interconnected locations. The introduction of FDI in the aeronautic sector in partners' countries confirms this intuition. Finally, we introduce a contractual friction variable that indicates that good institutions are a key determinant of trade in Europe but not with partners in the rest of the world. This result affirms a description offered by Grossman and Rossi-Hansberg (2012) about the fragmentation of the Boeing 787, for which the division of the supply chain mainly involved northern countries with minor technology differences but strong local advantages (driven by economies of scale).

In the next section, we outline several stylized facts about the aeronautic and space trade industries, including their main regions and clusters. To our knowledge, Section 2 is the first description in the literature of trade at the regional level in the aeronautic sector in

\footnotetext{
${ }^{2}$ http://www.elysee.fr/president/root/bank/print/5637.htm.
}

Million dollars

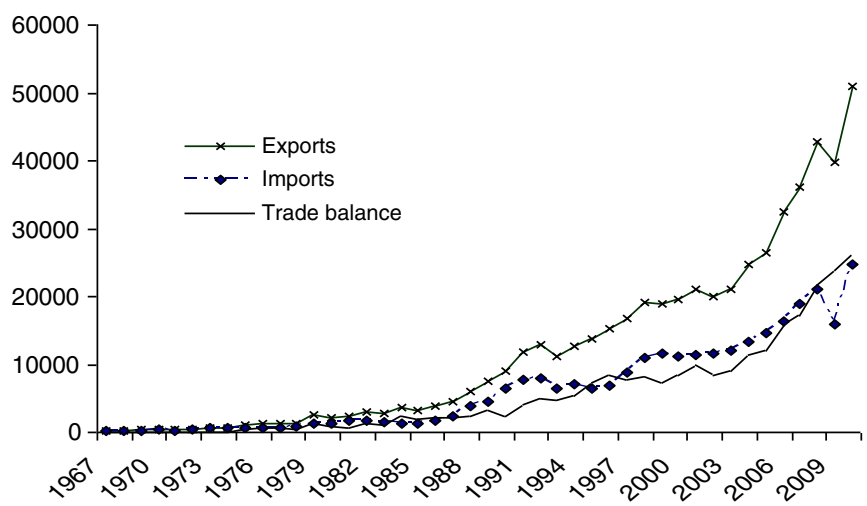

Fig. 1. Aeronautic and space trade in France. Source: Chelem (calculations of authors).

France. After describing aeronautic trade by French region, we show how it fits into a wider European network. This section describes in particular how exports in destination to the U.S. have decreased while in contrast exports to Germany have increased. These two elements potentially indicate the effect of the Euro appreciation and reorientation of the aeronautical sector inside the European Union. Lastly to illustrate this European network, this section presents the A380 production which is a symbolic element of the European factory. This huge project, at a time of a strong euro, may have strengthened the internal hub and spoke in Europe. The price competitiveness of the aeronautic sector is our focus in Section 3. A gravity equation is presented in Section 4, and we dedicate the next sections to estimate our proposed regional export (Section 5) and regional import (Section 6) equations. We conclude in Section 7.

\section{Trade and general description of France's aeronautic sector}

We describe briefly the evolution of exports and imports in the aeronautic sector during the 2000s, distinguishing total trade throughout France from trade by French region.

The first cluster leads the fields of executive aviation, space travel, and engines/equipment by bringing together more then 100,000 people, who perform the majority of sector-specific R\&D in France. Groups and organizations involved in this cluster include Dassault Aviation, Safran, Astrium, the CNES, and the European Space Agency, though the Safran group performs perhaps the most notable industrial activities. Aerospace Valley, a bi-regional aerospace cluster, leads the European aerospace, space travel, and embedded system sector, with a turnover of 10 billion euros. It comprises more than 200 companies, including international groups such as EADS, Freescale Semiconductors, Goodrich, Honeywell, and Siemens. In addition to a strong focus on Airbus-related activities, Aquitaine is home to industrial activities by Dassault Aviation and solid propulsion tests for the aerospace industry (mainly by EADS Space Transportation, Snecma Propulsion Solide, and SNPE). Finally, Provence-Alpes-Côte d'Azur hosts Eurocopter and Thales Alenia Space. These three clusters account for $78 \%$ of employment in the aerospace sector (Fig. 2).

\subsection{Trade}

French trade in the aeronautic industry has been characterized by fast import growth from the UE15 during 2003-2006, and then relative stagnation. In contrast, imports from the rest of the world (RoW) increased strongly over the same period (Fig. 3), indicating a possible impact of euro appreciation. 


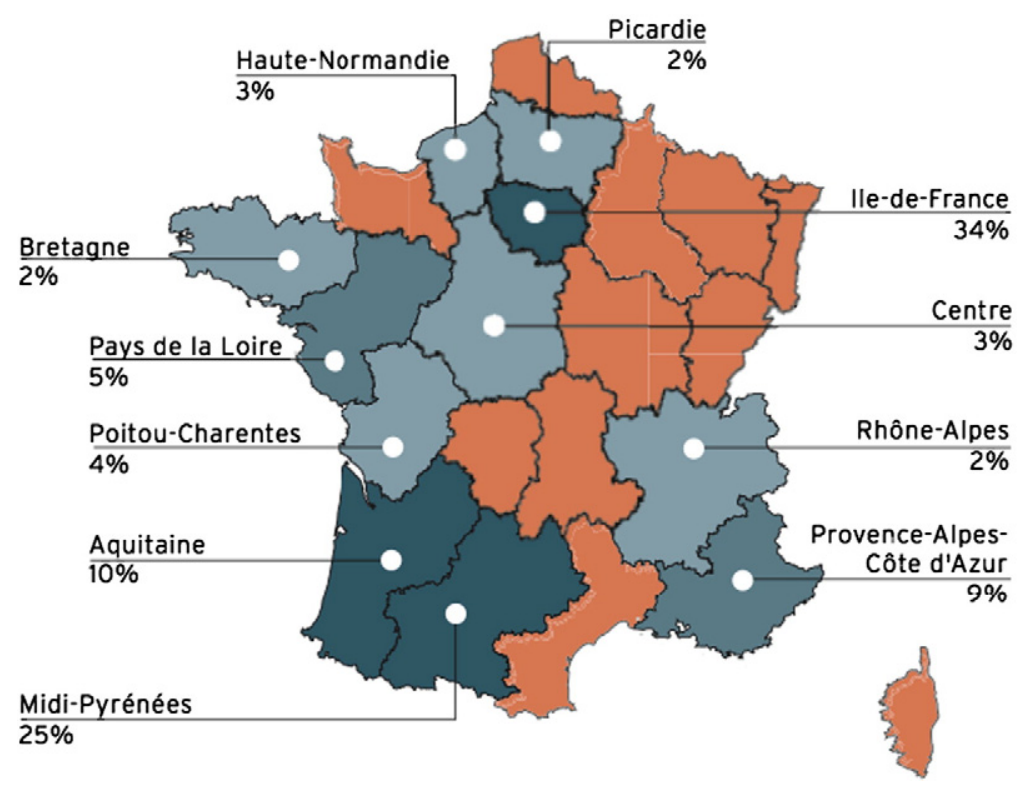

Less than $2 \%$

2 to $4 \%$

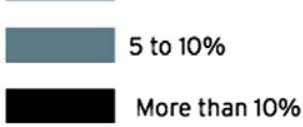

$80 \%$ of the workforce is concentraded in 5 regions

Fig. 2. Aerospace employment by French region (percentage). Source: GIFAS.

Despite this appreciation though, French exports to the RoW also increased during the 2000s (Fig. 4; cf. 2009, when the global recession hit).

In analyzing the shares of different destinations (Fig. 5), it becomes quickly clear that since the middle of the 1980s, the share of exports to the United States declined, with a negative trend from $41 \%$ to $14 \%$ of total exports, whereas in the same period, the share of exports to Germany increased, to reach $33 \%$ of the total in 2010. In addition, since the beginning of the 1990s, the share of exports to China increased to $10 \%$. These shifts confirm two overriding points: First, aeronautic sector firms have adjusted their strategies, to develop a European network and encourage strengthened relations between Germany and France. Second, exchanges with China have greatly increased. The decrease in U.S. exports may be a result of these changes, but it also probably stemmed from the overvaluation of the euro.

\subsection{Industry clusters and regional trade}

France comprises multiple administrative regions, each of which is subdivided into departments. Some industrial clusters overlap several regions, such as Aerospace Valley, which spans Aquitaine and MidiPyrénées; in all cases, they cover several departments. To analyze the exports of the three French aeronautic clusters, we present the evolution of exchanges by department.

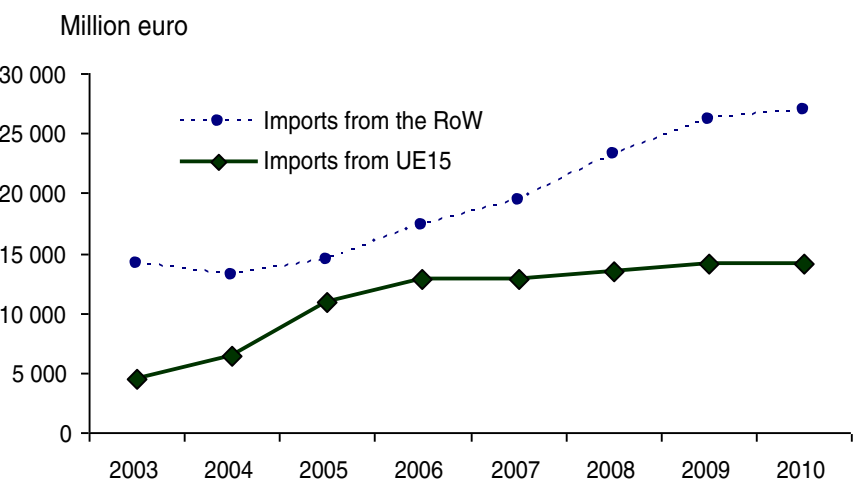

Fig. 3. French imports Source: DNSCE-Pôle statistique.

\subsubsection{ASTech Paris}

Ile de France (IDF) represents a central location, in that many goods are produced there, before being exported to Midi-Pyrénées for final production and assembly. As the main producer of aircraft and helicopters, as well as a key producer of spacecraft, launchers, and navigation equipment, IDF's aircraft industry employs 33,410 workers (as of 2010) (Buat, 2012). Although Seine-et-Marne clusters just a few firms, it is the regional export platform (Fig. 6).

\subsubsection{Aerospace Valley}

Fig. 7 indicates exports by two main departments in the two regions in which this cluster locates. Toulouse, in Haute-Garonne, is the main export city; its exports doubled between 2003 and 2011, from 13.7 to 31 billion euros. With its 2.4 billion euros in 2011, the neighboring region of Aquitaine is the third largest exporting region among aeronautic firms, which cluster around Bordeaux in Gironde and, to a lesser extent, in Pyrénées-Atlantiques. As Fig. 7 denotes though, the modern economic crisis halted the growth of aeronautic exports from Gironde.

\subsubsection{Pégase}

In the Provence-Alpes-Côte-d'Azur region, the Alpes-Maritimes and Bouches-du-Rhône are the most important departments with regard to aeronautic sector activity. Exports from Bouches-du-Rhône (Fig. 8)

\section{Million euro}

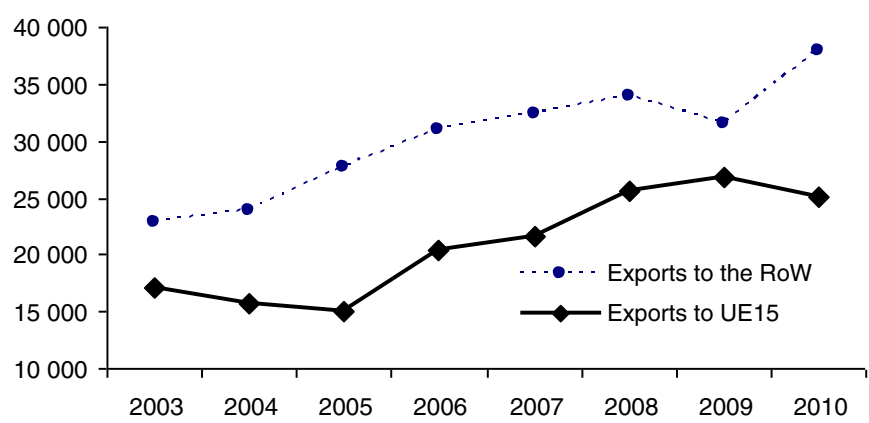

Fig. 4. French exports

Source: DNSCE-Pôle statistique. 


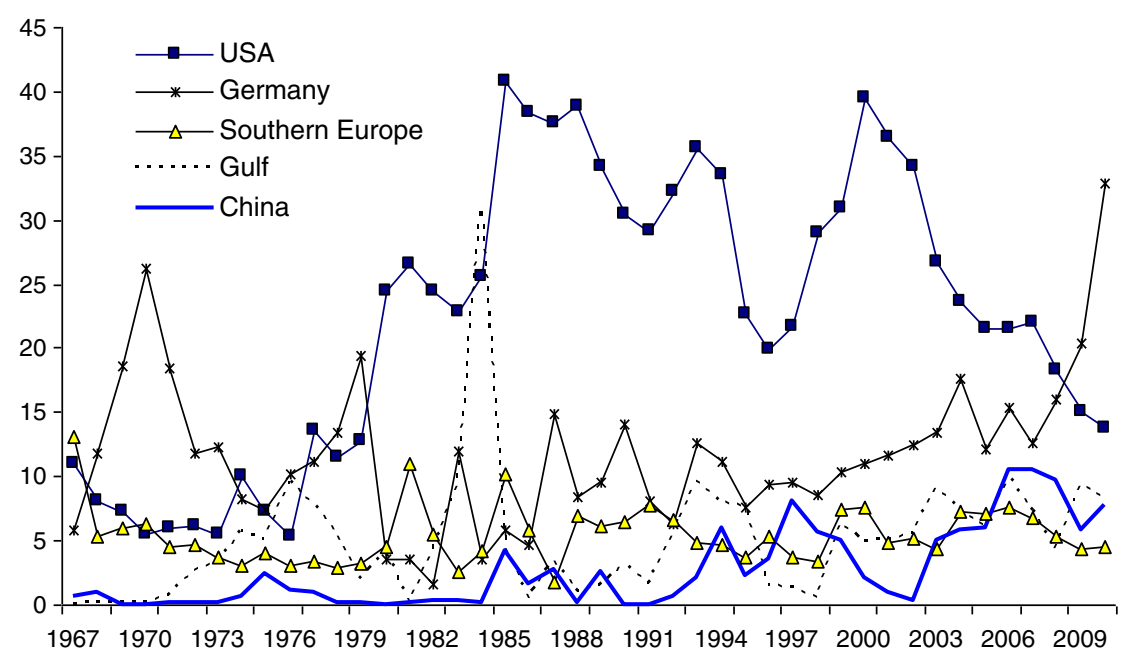

Fig. 5. Destinations of French aeronautic and space exports (percentage of total). Source: Chelem.

increased from 600 million euros in 2003 to 1056 million euros in 2011; those from the Alpes-Maritimes department remained relatively stable during this period, at approximately 300 million euros. Exports from other departments were limited, exhibiting values between 1 and 3 million euros.

To truly understand the trade flows in the aeronautic industry, we must reconsider the organization of this sector, which has developed as a network throughout Europe.

\subsection{European regional networks: a case study}

To investigate the core-periphery network that marks Toulouse at the French and European regional levels, we use the launch of Airbus' A380 aircraft as an interesting example. Map 1 details the logistic elements for the A380's construction, which demanded the involvement of several European countries. Specifically, special boats transport fuselages from Hamsbourg to Mostyn (UK), where they take on wings manufactured in Broughton. Next, they go to Saint-Nazaire (Pays de la Loire), where the boats onload the cockpit and aircraft nose sections, received from Méaulte (Picardie) by Beluga. Finally, the travels end in Aquitaine, passing below Bordeaux bridges (though only at low tide). From Bordeaux (i.e., Langon) to Toulouse (Blagnac), parts of the plane

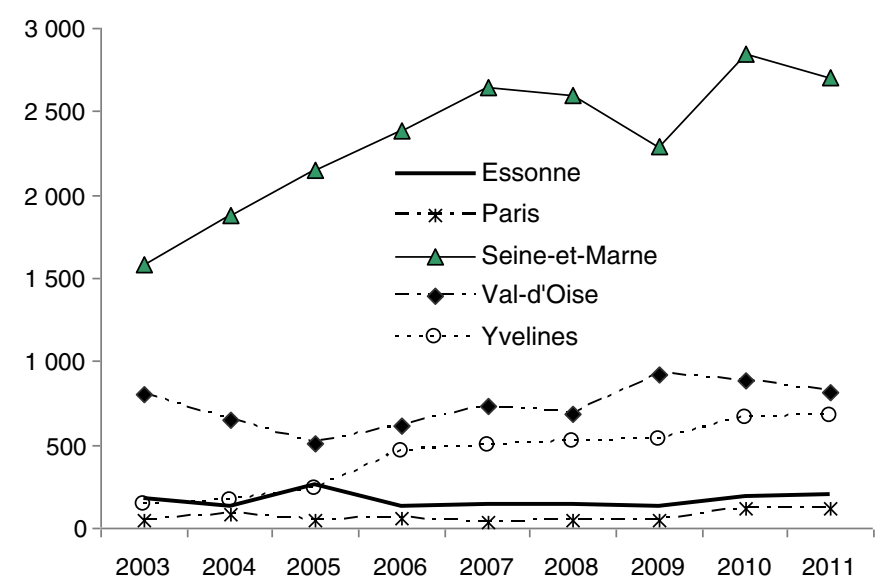

Fig. 6. Exports by the ASTech Paris cluster. Source: DNSCE-Pôle statistique (million euros). get transported by special trucks over $237 \mathrm{~km}$ of road; the same road is the route for the tail plane parts that come from Cadix (Puerto Real).

The significant investment required to build the $A 380$ reflects the efforts by the European aeronautic sector to retain its global ranking. This network is representative of the general strategy adopted by the

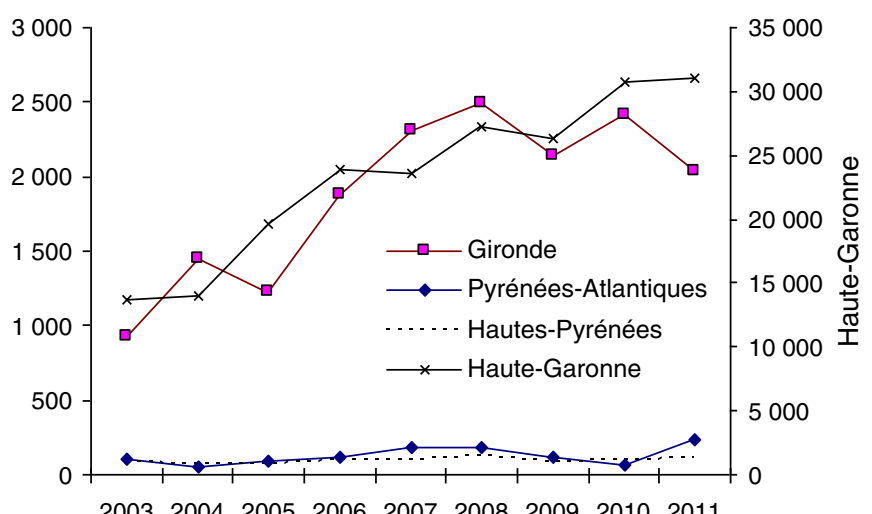

Fig. 7. Exports by the Aerospace Valley cluster. Source: DNSCE-Pôle statistique (million euros).

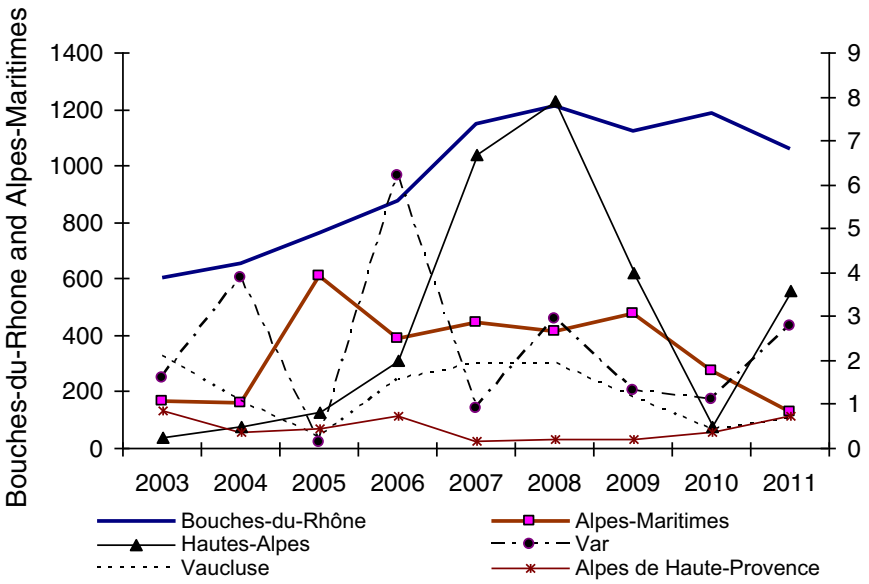

Fig. 8. Exports by the Pégase cluster. Source: DNSCE-Pôle statistique (million euros). 


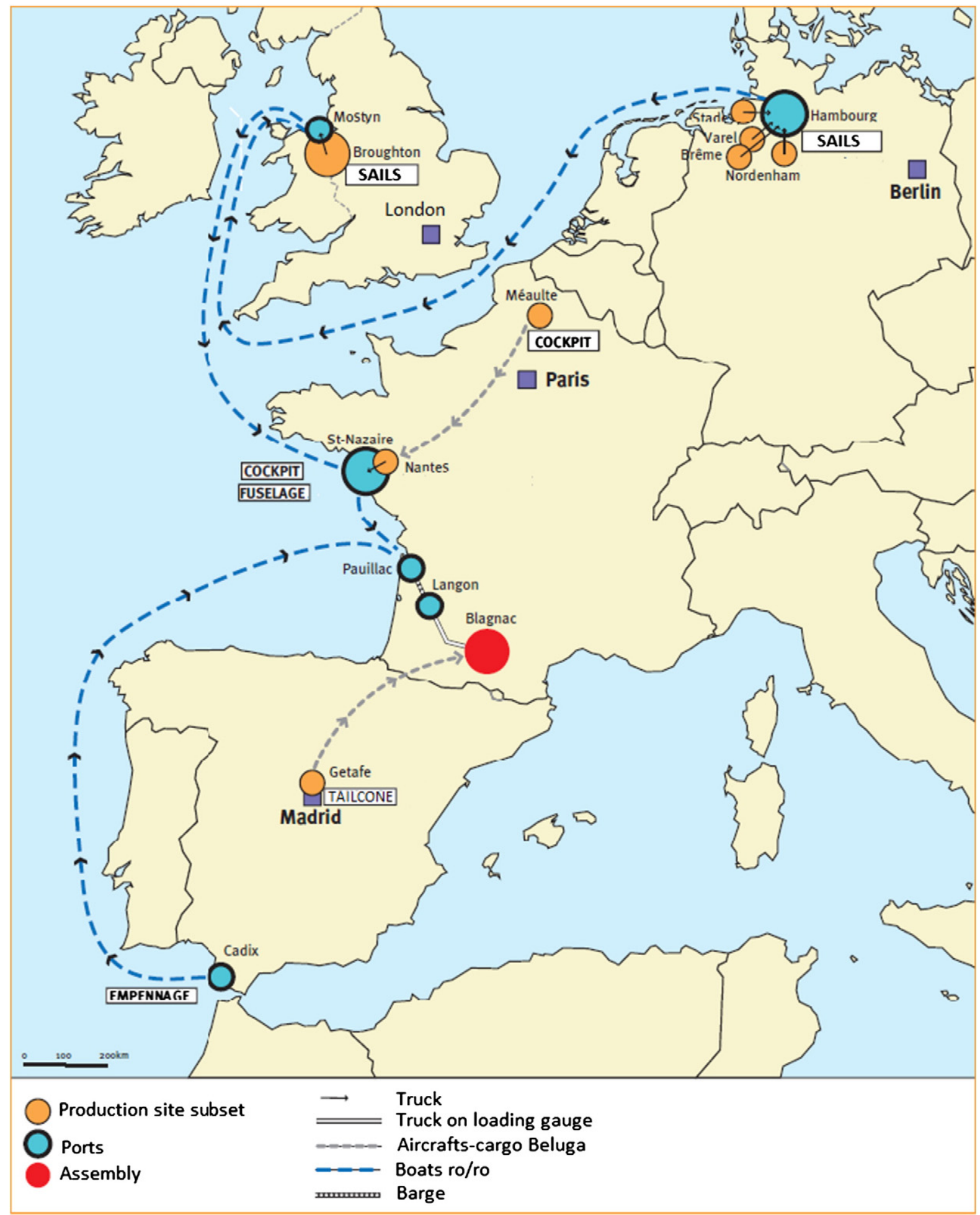

Map 1. Transport network for the A380.

Source: Zuliani and Jalabert (2005, p. 129)

European aeronautic industry and results from the influences of both political and economic factors. The choice also has several economic consequences. First, this strategy ensures that production is not concentrated in one area but instead favors the development of different European regions, with positive effects that may spread throughout the economy (e.g., outsourcing). Second, the existence of these networks helps contribute to the development of intra-European trade.

\section{Price competitiveness}

As noted in the Introduction section, the world aeronautic market mainly features competition between Europe and the United States. Therefore the euro-dollar exchange rate is important, and price or cost competitiveness is a fundamental variable determining aeronautic equipment sales worldwide. 


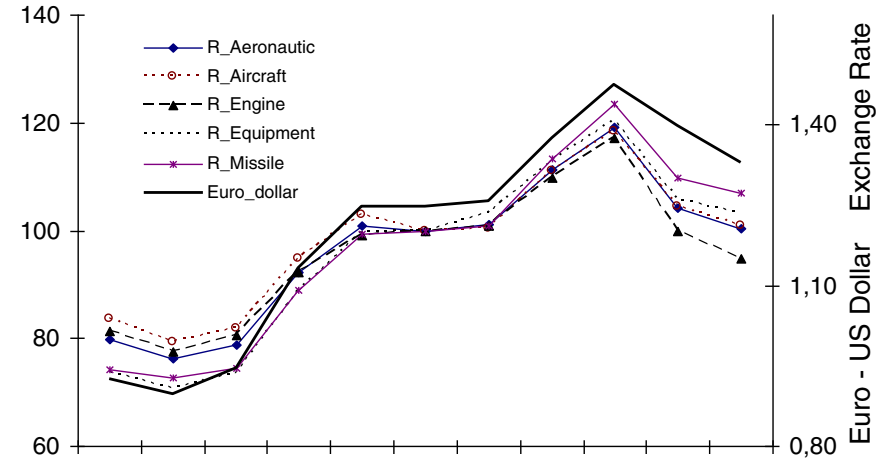

20002001200220032004200520062007200820092010

Fig. 9. Real exchange rates by product.

\subsection{Why is the euro-dollar exchange rate important?}

Because of the central duopoly of the aircraft market (Airbus versus Boeing), the euro-dollar exchange rate is an essential feature in determining firms' strategies. The invoice currency for the international trade of aircraft and spacecraft is the U.S. dollar, so for constant margins, a depreciation of the dollar (cf. appreciation of the euro) implies a reduction (cf. rise) in Airbus's revenues expressed in euros. In addition, a dollar depreciation or euro appreciation increases the export prices for Airbus in dollars, except if the export price, as expressed in the exporter's currency, is reduced.

Bénassy-Quéré et al. (2011) propose a duopoly model of the market for Airbus's A320 and Boeing's 737 aircraft families. The model simulates the impact of an appreciation by the euro. Estimating that price elasticities for aircraft exports to demand are equivalent to a ratio of 2-to-6, depending on the destination markets, they conclude that a euro appreciation of $10 \%$ that passes completely through to the prices of imported goods (no reduction of margins) reduces "Airbus sales by $20-60 \%$ in volume and $10-50 \%$ in euro-denominated value" (BénassyQuéré et al., 2011, p. 627). However, if French producers absorb some exchange rate variations, incomplete pass-through occurs. Generally, adjustments in the margins of producers, to avoid passing on all exchange rate variations to the prices of imported aircraft, depend on the price elasticity of aircraft demand. In turn, Airbus faces a dilemma, because its sales are denominated in dollars, but its production sites are in France, Germany, and Spain, in the euro zone. In contrast, Boeing is protected from exchange rate changes because it produces and sells in dollars.

\subsection{Measure of price competitiveness}

To characterize price competitiveness, we consider the behavior of relative prices and real exchange rates for key segments of the aerospace market. For the aerospace sector, the relative price, or bilateral real exchange rate, between France and the United States $\left(R_{\text {Fra/USA }}\right)$ is

$R_{\text {Fra } / \text { USA }}=\frac{N \cdot P}{P^{*}}$

where $N$ represents the nominal exchange rate of the euro against the U.S. dollar, $P$ is the industry producer price of France, and $P^{*}$ is the price for the U.S. aerospace industry. ${ }^{3}$ An increase in $R$ reflects a real appreciation of the euro and thus a loss in competitiveness for the French industry. Because data on U.S. deflators are available for aircraft manufacturing, engine manufacturing, aircraft equipment, and missiles, ${ }^{4}$ we can calculate different real exchange rates for each index.

\footnotetext{
${ }^{3}$ For France, this price index is not available. Calculations with the production price index for French industry, beyond specific markets, to include all areas and transport equipment, lead to similar results.

4 Source: Aerospace Industries Association, Bureau of Labor Statistics and Bureau of Economic Analysis.
}

Thus, for $i=$ aircraft manufacturing, engine manufacturing, aircraft equipment, or missiles, $P_{i}^{*}$ is the price of a product by $i$, and the real exchange rate can be rewritten as $R_{\mathrm{Fra} / \mathrm{USA}, i}=N \cdot \mathrm{P} / \mathrm{P}_{i}^{*}$.

At first glance, swings in the real exchange rate and depreciation/ appreciation phases appear linked to fluctuations of the nominal exchange rate for the euro/dollar (Fig. 9). The strong real appreciation between 2001 and 2008 coincides with the appreciation of the euro and likely explains the fears of the European aerospace industry. According to GIFAS ${ }^{5}$ chairperson J.-P. Herteman, every 10 cents that the euro rises above this "balanced" rate means an average $2 \%$ loss in operating profit on revenue, such that "Over the last three years this makes more than 4 billion in lost earnings, or the equivalent of two years' selffinanced research and development or 7000 jobs a year not created in France" (Apter, 2010). ${ }^{6}$ In truth though, behaviors vary with the different products. During the period, we observe changes in competitiveness, namely, in the relative prices of products between France and the United States. A stronger real appreciation/rise of relative prices is observable for the missiles, but the increases in the relative prices of engines and aircrafts appear more limited. That is, France improved its competitiveness in the production of engines and, to a certain extent, aircraft, but it lost competitiveness in the production of missiles. Increased international competition in some product markets could have led U.S. producers to adapt their margins and their costs. (See Fig. 10.)

\section{Theoretical and empirical strategies}

To our knowledge, the gravity equation, which is the most common tool to analyze trade at the product and industry level (see Helpman et al., 2008), has not yet been used to analyze France's aeronautic trade. Consider the standard gravity equation obtained by Anderson and van Wincoop (2003):

$X_{i j}=\frac{y_{i} y_{j}}{\Pi_{j} \Pi_{i}} \tau_{i j}{ }^{1-\sigma}$,

where bilateral exports $X_{i j}$ depend on expenditures/production in the aeronautical sector in each country $\left(y_{i} y_{j}\right)$, on price indices $\left(\Pi_{j} \Pi_{i}\right)$, and on an inverse measure of bilateral trade costs $\left(\tau_{i j}{ }^{1-\sigma}\right.$ with sigma as the elasticity of substitution between varieties).

A wide range of theoretical models, from oligopolistic to monopolistic, as well as those based on national product differentiation and comparative advantages, with and without non-homothetic preferences, provide similar equations (see Candau and Dienesch, 2011; Head and Mayer, 2011). The appeal of Anderson and van Wincoop's (2003) model is that the production function is not specified and thus can be extended to include various factors. ${ }^{7}$ Inspired by Kremer (1993, eq. 31) we assume that the production process requires tasks that are complementary and located in different countries, such as ${ }^{8}$ :

$y_{i}=\left(q_{i} k_{i}\right)^{\varphi_{i}}\left(q_{j} k_{j}\right)^{\psi_{i}}$

where $q_{i}$ is a worker's skill at a particular task; $k_{i}$ is the amount of capital; and $\varphi_{i}$ and $\psi_{i}$ represent domestic technology, including requirements for input produced locally and abroad, respectively. In the extreme case at

\footnotetext{
5 Groupement des Industries Françaises Aéronautiques et Spatiales.

${ }^{6}$ See http://www.ainonline.com/aviation-news/farnborough-air-show/2010-07-21/ french-aerospace-awaits-2011-recovery. Many officials of the French and European aeronautic industries appear to consider the equilibrium exchange rate for this industry to be around $\$ 1.20$ per euro. This type of statement is not supported by a possible model of equilibrium exchange rates of a particular industry.

${ }^{7}$ Anderson (2011) speaks about "modularity" and Anderson et al. (2014) exploit this property to introduce external economies of scale.

8 Notice that the Armington's assumption of Anderson and van Wincoop's (2003) consideration that goods are differentiated by country of origin is here verified by the elasticity of substitution between factors that are specific to the country where the good is produced.
} 


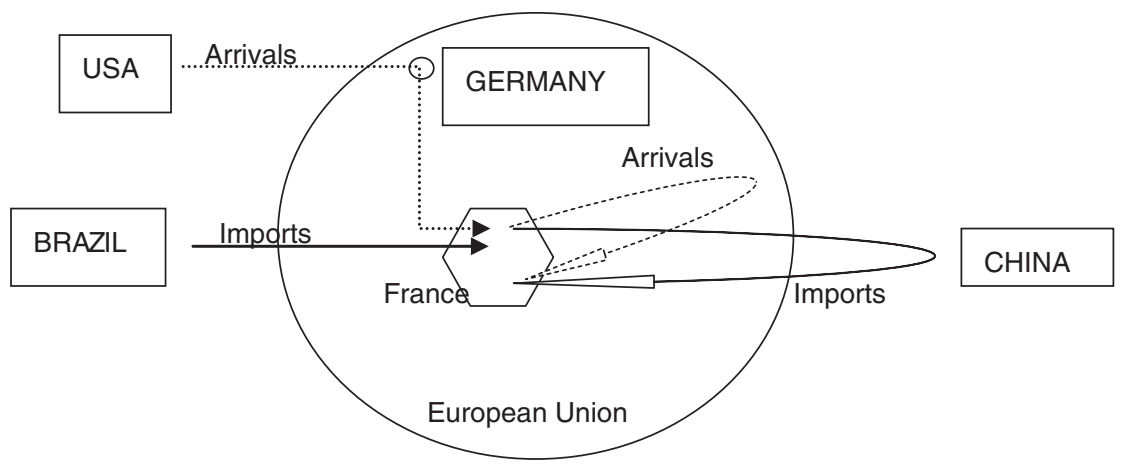

Fig. 10. Import and arrival schematic.

which $\psi_{i}=0$, domestic production only depends on domestic input (if $\varphi_{i}=0$, the country $i$ is only a platform where assembly occurs), but at positive values of this parameter, the amount of capital and expertise of workers in partners' countries become crucial too. If a worker performs badly or physical capital malfunctions, the supply chain might be broken.

We estimate a reduced form of this model by directly inserting this expression (and its counterpart for country $j$ ) $^{9}$ in Eq. (1):

$X_{i j}=\frac{\left(k_{i} q_{i}\right)^{\psi_{j}+\varphi_{i}}\left(k_{j} q_{j}\right)^{\psi_{i}+\varphi_{j}}}{\Pi_{j} \Pi_{i}} \tau_{i j}{ }^{1-\sigma}$.

Although a standard gravity equation would predict that economical masses (e.g., GDP of country $i$ and GDP of country $j$ ) influence trade flows in the same way (with an elasticity of income equal to 1 , as in Eq. (4)), here we have no reason to expect that $\psi_{i}+\varphi_{j}=\psi_{j}+\varphi_{i}=1$. Instead, the production process likely involves asymmetrical relationships. For example, the following ranking

$\psi_{j}+\varphi_{i}>1>\psi_{i}+\varphi_{j}>0$

indicates that exports from $i$ to $j$ benefit from economies of scale at $i$ (which is possible even if there are decreasing returns at the factor level, as in Kremer (1993, p. 571), when $\psi_{j}<1$ and $\varphi_{i}<1$ ) and from diseconomies from outsourcing/producing in $j .^{10}$

The next step is to understand firms' incentives to outsource their production to the partner country. In contrast with models in which lower costs of production abroad are the determinants, the supply chain in the aeronautic sector may be weakened by relocation to countries where capital and skills are low, but the overvaluation of the exchange rate also can be a determinant of relocation. If the euro is overvalued, firms might find it profitable to relocate their activities outside the euro area in countries with similar levels of technology. This situation can occur if the exchange rate constitutes a cost in the bilateral relationship. We follow prior literature (e.g., Anderson et al., 2014) and consider the function of bilateral trade costs as follows:

$\tau_{i j}=e_{i j} d_{i j} \exp \left(b_{E U}\right)$,

where $e_{i j}$ represents the exchange rate, $d_{i j}$ is the distance between partners, and $b_{E U}$ is a dummy variable, equal to 1 for intra-European flows and 0 otherwise. With this dummy variable, we can determine if there is a European border effect in the aeronautic industry.

\footnotetext{
${ }^{9}$ It may be interesting to obtain the demand of capital and labor at equilibrium and insert these expressions into the gravity equation. We leave this effort for future research; Mirza and Nicoletti (2004) offer a first step.

10 We do not restrict these parameters; a total opposite ranking may be observed, but inequality (Eq. (4)) seems most natural.
}

Regarding the exchange rate, we successively consider the nominal dollar-euro rate and the four measures of real exchange rates described in the previous section. Inserting Eq. (5) in Eq. (3) and taking the logarithm gives:

$$
\begin{aligned}
\ln X_{i j}= & \left(\psi_{j}+\varphi_{i}\right) \ln q_{i}+\left(\psi_{i}+\varphi_{j}\right) \ln q_{j}+\ln \left(k_{i}^{{ }^{\psi_{j}+\varphi_{i}}} k_{j}{ }^{\psi_{i}+\varphi_{j}}\right) \\
& +(1-\sigma) \ln e_{i j}+(1-\sigma) \ln d_{i j}+b_{E U}
\end{aligned}
$$

As a proxy for workers' productivity $q_{i}$ and $q_{j}$, we use GDP per capita. To measure $k_{i}^{\psi_{j}+\varphi_{i}} k_{j}{ }^{\psi_{i}+\varphi_{j}}$, we use different variables, including both standard options, such as FDI in the aeronautic sector and R\&D, as well as more specific measures, such as military spending. Denoted by $m_{j}$, military spending often focuses on high-tech products. For developing countries in particular, increased military spending likely winds up in the hands of foreign exporters rather than locals. Furthermore, even in north-north relationships, military spending can promote specific knowledge in each nation, which can be useful for developing complementary inputs, as suggested by O-ring theory. Similarly, in describing the supply chain of the Boeing 747, Grossman and Rossi-Hansberg (2012) highlight the importance of trade between northern countries, due to the specialized knowledge developed in this sector; they even note the influence of military spending: "countries that perform the various tasks display no clear pattern of technological advantage. Rather, experience and local knowledge play a central role. Apparently, expertise most often derives from similar tasks being performed for other Boeing projects or for related industries, such as military aviation."

We include an indicator of air transport (carriers' departures worldwide) to proxy for partner demand for aircraft products. Finally, the price of oil might affect trade in the aeronautic sector; a price increase likely exerts a negative short-run effect by prompting consumers to defer their purchases but a positive long-run effect through the purchase of more efficient aircraft technologies ultimately. Thus, the benchmark equation estimated with ordinary least squares (OLS) is: $X_{i j t}=$ $\beta_{1} \ln y_{i t}+\beta_{2} \ln y_{j t}+\beta_{3} \ln e_{t}+\beta_{4} \ln m_{j t}+\beta_{5} \ln o_{t}+\beta_{6} \ln d_{i j}+\beta_{7} \ln$ $a_{j t}+b_{E U}+\varepsilon_{i j t}$.

We summarize the study variables in Table 2 .

\section{Export equations}

We present the estimates of the export equations in Table 3. A first striking result pertains to the strong coefficient of French regional GDP per capita, which is much stronger than the coefficient of GDP per capita in the partner country, in support of our assumption about economies of scale in the country of origin (inequality (4)). The positive significant impact of partner GDP per capita suggests evidence of a north-north relationship in the production process, as indicated by O-ring theory.

The negative impact of exchange rate also is noteworthy and stronger than any other determinant. We observe that a gain of $1 \%$ in French 
Table 2

Data sources.

\begin{tabular}{lll}
\hline Variable & Name & Source \\
\hline$y_{i t}$ & French regional income per capita & INSEE \\
$y_{j t}$ & National GDP per capita & GDP: IFS \\
& & Population: WDI database \\
$e_{i j t}$ & Nominal exchange rate $€ / \$$ & IFS \\
$o_{t}$ & Oil price & IFS \\
$m_{j t}$ & Military spending & SIPRI \\
$d_{i j}$ & Distance & CEPII \\
$a_{j t}$ & Air transport & WDI database \\
$r_{j t}$ & R\&D & STAN
\end{tabular}

Notes: All variables are expressed in thousands of dollars.

INSEE for Institut National de la Statistique et des Etudes Economiques; IFS for International Financial Statistics; WDI for World Development Indicators; SIPRI for Stockholm International Peace Research Institute; CEPII for Centre d'Études Prospectives et d'Informations Internationales and STAN for Structural Analysis, OECD databases.

productivity can be offset by a $1 \%$ increase in the nominal exchange rate, because trade elasticities are similar (i.e., 5.2 and -5.35 ).

Moreover, this result appears robust. Only the coefficient of the relative price of engines is not significant; notably, for these products, appreciation is lower too (Fig. 9). This result may indicate that engine manufacturers have undertaken more price-related efforts than other firms in the industry.

Air transport, as measured by registered carrier departures, fosters exports of French firms, likely due to the strong market entry of these firms into hub airports, for which maintenance is a serious concern.

Similarly, military expenditures by partners benefit the French aeronautic industry. This result clearly supports Grossman and RossiHansberg's (2012) prediction of the importance of specific knowledge. The result also is noteworthy, in that it opposes a counterargument. For security reasons, nations prefer domestic producers, such that a rise in public demand in $j$ might not affect production in $i$. Brülhart and Trionfetti (2009) show that nationally discriminatory public procurement in Europe reduces trade. The positive impact we find instead indicates that the home bias problem can be overtaken by international

Table 3

Export equation: ordinary least squares.

\begin{tabular}{|c|c|c|c|c|c|}
\hline & \multirow{2}{*}{$\begin{array}{l}\text { Nominal } \\
\text { exchange } \\
\text { rate }\end{array}$} & \multicolumn{4}{|c|}{ Real exchange rate } \\
\hline & & Aeronautic & Aircraft & Engine & Equipment \\
\hline \multirow[t]{2}{*}{$y_{i}$} & $5.2^{* * *}$ & $5.06^{* * *}$ & $5.07^{* * *}$ & $5.01^{* * *}$ & $5.06^{* * *}$ \\
\hline & 0.2 & 0.19 & 0.2 & 0.19 & 0.19 \\
\hline \multirow[t]{2}{*}{$y_{j}$} & $0.24^{* * *}$ & $0.23^{* * *}$ & $0.23^{* * *}$ & $0.23^{* * * *}$ & $0.24^{* * *}$ \\
\hline & 0.03 & 0.03 & 0.03 & 0.03 & 0.03 \\
\hline \multirow[t]{2}{*}{$e_{i}$} & $-5.35^{* * * *}$ & $-2.09^{* *}$ & $-2.19^{* *}$ & -0.68 & $-2.91^{* * *}$ \\
\hline & 1.14 & 0.94 & 0.01 & 0.77 & 0.97 \\
\hline \multirow[t]{2}{*}{$m_{j}$} & $0.18^{* * *}$ & $0.18^{* * *}$ & $0.18^{* * * *}$ & $0.18^{* * *}$ & $0.19^{* * *}$ \\
\hline & 0.03 & 0.03 & 0.03 & 0.03 & 0.03 \\
\hline \multirow[t]{2}{*}{$a_{j}$} & $0.65^{\text {**** }}$ & $0.65^{\text {*** }}$ & $0.65^{* * *}$ & $0.65^{* * * *}$ & $0.64^{\text {**** }}$ \\
\hline & 0.04 & 0.04 & 0.04 & 0.04 & 0.04 \\
\hline \multirow[t]{2}{*}{$o_{t}$} & $-0.64^{* * *}$ & $-1.23^{* * *}$ & $-1.36^{* * *}$ & $-1.54^{* * *}$ & $-0.70^{* *}$ \\
\hline & 0.23 & 0.18 & 0.16 & 0.16 & 0.33 \\
\hline \multirow[t]{2}{*}{$d_{i j}$} & $-0.12^{* * *}$ & $-0.12^{* * *}$ & $-0.12^{* * *}$ & $-0.12^{* * *}$ & $-0.12^{* * *}$ \\
\hline & 0.01 & 0.01 & 0.01 & 0.01 & 0.01 \\
\hline \multirow[t]{2}{*}{$b_{E U}$} & $-1.00^{* * * *}$ & $-0.99^{* * *}$ & $-0.99^{* * *}$ & $-0.99^{* * *}$ & $-1.00^{* * *}$ \\
\hline & 0.12 & 0.12 & 0.12 & 0.12 & 0.12 \\
\hline \multirow[t]{2}{*}{ Intercept } & $16.81^{* *}$ & $-9.38^{* * *}$ & $-8.63^{* *}$ & $-14.46^{* * *}$ & $-8.27^{* * *}$ \\
\hline & 0.94 & 1.27 & 3.83 & 1.94 & 3.13 \\
\hline $\mathrm{R}^{2}$ & 0.25 & 0.25 & 0.25 & 0.25 & 0.25 \\
\hline Obs. & 5819 & 5819 & 5819 & 5819 & 5819 \\
\hline
\end{tabular}

Notes: Robust standard errors appear under the coefficients.

*** Significant at $1 \%$.

** Significant at $5 \%$
Table 4

Export equation: individual fixed effects.

\begin{tabular}{lcc}
\hline & Nominal exchange rate & Real exchange rate \\
\hline$y_{i}$ & $5.99^{* * *}$ & $5.78^{* * *}$ \\
& 0.74 & 0.73 \\
$y_{j}$ & 0.17 & 0.19 \\
& 0.18 & 0.18 \\
$e_{t}$ & $-7.93^{* *}$ & $-3.5^{* *}$ \\
& 3.99 & 3.6 \\
$m_{j}$ & $1.39^{* *}$ & $1.27^{* *}$ \\
$a_{j}$ & 0.58 & 0.58 \\
& -0.03 & 0.10 \\
$o_{t}$ & 0.56 & 0.56 \\
& -0.52 & $-1.3^{*}$ \\
$d_{i j}$ & 0.8 & 0.18 \\
& $-0.05^{* *}$ & $-0.05^{*}$ \\
$r_{j t}$ & 0.02 & 0.02 \\
Intercept & $-0.18^{* *}$ & $-0.17^{* *}$ \\
& 0.09 & 0.09 \\
$\mathrm{R}^{2}$ & 8.81 & $-25.7^{*}$ \\
Obs & 24 & 14 \\
\hline
\end{tabular}

Notes: Robust standard errors appear under the coefficients.

*** Significant at $1 \%$.

** Significant at $5 \%$.

* Significant at $10 \%$.

fragmentation of the supply chain. Due to global network effects, an increase in military spending in $j$ fosters exports by $i$.

As expected, because it increases final usage costs, the price of oil is detrimental for exports.

However, not controlling for unobserved or individual effects might lead to bias in the resulting estimates. We reduced the partners' heterogeneity through sample selection. That is, we estimated our equations with data obtained exclusively from exports to OECD partners. Working with these countries improves the analysis by introducing a key variable: R\&D expenditures in the aeronautic sector (obtained from the STAN database). We provide the results in Table 4. In particular, we note that the exchange rate and military spending have stronger effects on exports to OEDC partners, which confirms existing results. More surprising with regard to O-ring theory is the negative impact of partners' expenditures in R\&D, which implies that the competition effect, not taken into account by this theory, also has a role in the aeronautical sector.

Let's now turn toward the econometric technique. The sample selection technique is not ideal for getting an overall picture of trade though. The log-linearization also creates sample selection bias, by eliminating zero flows, which is problematic because beyond inter- and intratrade (or one- and two-way trade), a third major category exists: no trade. ${ }^{11}$ In this case, heteroskedasticity is a serious problem, because the distribution of bilateral trade data likely corresponds to a Poisson distribution. Using Monte Carlo simulations, Santos Silva and Tenreyro (2006, 2009) show that the Poisson pseudo-maximum likelihood (PPML) offers an efficient estimator for dealing with heteroskedasticity. We follow their methodology and treat zero trade flows using PPML. We thus work with the whole sample of countries and include both importer and exporter fixed effects, as we summarize in Table 5.

Many variables still have explanatory power, such as the exchange rate, air transport, and the price of oil. Some part of the economies of scale that are invariant in time can be captured by fixed effects, which reveals that regions in which the main clusters are located experienced stronger effects. The fixed effects for regional exporters are highly significant, with the highest impact obtained for Midi-Pyrénées, IDF, and Aquitaine. Military expenditures, invariant in time, are no longer

\footnotetext{
11 Investigating 158 countries, Helpman et al. (2008) find that two-way trade represents $30 \%$, one-way $10 \%$, and no trade can represent up to $60 \%$, depending on the year.
} 
Table 5

Export equation: PPML method.

\begin{tabular}{|c|c|c|c|c|c|}
\hline & \multirow{2}{*}{$\begin{array}{l}\text { Nominal } \\
\text { exchange } \\
\text { rate }\end{array}$} & \multicolumn{4}{|c|}{ Real exchange rate } \\
\hline & & Aeronautic & Aircraft & Engine & Equipment \\
\hline \multirow[t]{2}{*}{$y_{i}$} & $4.37^{* * *}$ & $2.52^{* * *}$ & $2.50^{\text {**** }}$ & $2.19^{* * *}$ & $0.84^{* * *}$ \\
\hline & 1.37 & 0.00 & 0.00 & 0.00 & 0.00 \\
\hline \multirow[t]{2}{*}{$y_{j}$} & $0.44^{* * *}$ & $0.54^{\text {*** }}$ & $0.53^{* * *}$ & $0.54^{* * *}$ & 0.51 \\
\hline & 0.36 & 0.00 & 0.37 & 0.37 & 0.36 \\
\hline \multirow[t]{2}{*}{$e_{t}$} & $-3.48^{* * *}$ & $-1.44^{* * *}$ & $-1.35^{* * *}$ & $-1.05^{* * *}$ & $1.64^{* * *}$ \\
\hline & 0.00 & 0.00 & 0.00 & 0.00 & 0.00 \\
\hline \multirow[t]{2}{*}{$m_{j}$} & -0.37 & -0.5 & -0.48 & -0.52 & -0.44 \\
\hline & 0.30 & 0.32 & 0.32 & 0.32 & 0.31 \\
\hline \multirow[t]{2}{*}{$a_{j}$} & $0.25^{*}$ & $0.24^{*}$ & $0.25^{*}$ & $0.24^{*}$ & $0.26^{*}$ \\
\hline & 0.14 & 0.14 & 0.15 & 0.14 & 0.14 \\
\hline \multirow[t]{2}{*}{$o_{t}$} & $-0.20^{* * *}$ & $-0.05^{* * *}$ & $-0.1^{* * *}$ & $-0.02^{* * *}$ & $-0.25^{* * *}$ \\
\hline & 0.00 & 0.00 & 0.00 & 0.00 & 0.00 \\
\hline \multirow[t]{2}{*}{$d_{i j}$} & -0.27 & 0.36 & 0.6 & 0.43 & 1.36 \\
\hline & 1513 & 1512 & 1513 & 1511 & 1604 \\
\hline \multirow[t]{2}{*}{ Intercept } & 15.9 & -0.03 & -2.91 & -1.23 & -8.14 \\
\hline & 13,578 & 13,569 & 13,578 & 13,564 & 3107 \\
\hline \multirow[t]{2}{*}{ Midi } & $5.69^{* * *}$ & $5.5^{* * *}$ & $5.5^{* * *}$ & $5.46^{* * *}$ & $5.32^{* * *}$ \\
\hline & 0.57 & 0.55 & 0.55 & 0.56 & 0.55 \\
\hline \multirow[t]{2}{*}{ IDF } & $2.71^{* * *}$ & $3.54^{* * *}$ & $3.55^{\text {*** }}$ & $3.69^{* * *}$ & $4.29^{* * *}$ \\
\hline & 0.82 & 0.63 & 0.63 & 0.62 & 0.63 \\
\hline \multirow[t]{2}{*}{ Aquitaine } & $4.04^{* * *}$ & $3.84^{* * *}$ & $3.85^{* * *}$ & $3.81^{* * *}$ & $3.67^{* * *}$ \\
\hline & 0.00 & 0.00 & 0.00 & 0.00 & 0.00 \\
\hline $\begin{array}{l}\text { Fixed effects } \\
\text { (departments }+ \\
\text { partners) }\end{array}$ & Yes & Yes & Yes & Yes & Yes \\
\hline Obs. & 10,011 & 10,011 & 10,011 & 10,011 & 10,011 \\
\hline Pseudo $\mathrm{R}^{2}$ & 0.58 & 0.58 & 0.58 & 0.58 & 0.58 \\
\hline
\end{tabular}

Notes: Robust standard errors appear under the coefficients.

*** Significant at $1 \%$.

* Significant at $10 \%$.

significant, which is logical because their effects can be captured by partner fixed effects.

Despite these controls and the change in the estimator, inequality (Eq. (4)) still can be verified, which reinforces the argument of strong complementary between factors in France and abroad as an explanation of trade in the aeronautic sector.

Table 6

Import equation: ordinary least squares.

\begin{tabular}{|c|c|c|c|c|c|}
\hline & \multirow{2}{*}{$\begin{array}{l}\text { Nominal } \\
\text { exchange } \\
\text { rate }\end{array}$} & \multicolumn{4}{|c|}{ Real exchange rate } \\
\hline & & Aeronautic & Aircraft & Engine & Equipment \\
\hline \multirow[t]{2}{*}{$y_{i}$} & 0.79 & 0.90 & $0.93^{*}$ & $1.08^{* *}$ & $1.45^{* *}$ \\
\hline & 0.77 & 0.55 & 0.56 & 0.51 & 0.53 \\
\hline \multirow[t]{2}{*}{$y_{j}$} & $0.20^{* * *}$ & $0.20^{* * *}$ & $0.20^{* * *}$ & $0.20^{* * *}$ & $0.20^{* * *}$ \\
\hline & 0.02 & 0.02 & 0.02 & 0.02 & 0.02 \\
\hline \multirow[t]{2}{*}{$e_{t}$} & 1.31 & $1.50^{* *}$ & $1.33^{*}$ & $1.34^{* *}$ & -0.01 \\
\hline & 1.19 & 0.70 & 0.71 & 0.52 & 0.72 \\
\hline \multirow[t]{2}{*}{$m_{j}$} & $0.34^{* * *}$ & $0.35^{* * *}$ & $0.35^{* * *}$ & $0.35^{* * *}$ & $0.35^{* * *}$ \\
\hline & 0.03 & 0.03 & 0.03 & 0.03 & 0.03 \\
\hline \multirow[t]{2}{*}{$a_{j}$} & $0.39^{* * *}$ & $0.39^{* * *}$ & $0.39^{* * *}$ & $0.39^{* * *}$ & $0.39^{* * *}$ \\
\hline & 0.03 & 0.03 & 0.03 & 0.03 & 0.03 \\
\hline \multirow[t]{2}{*}{$o_{t}$} & -0.14 & -0.17 & -0.12 & -0.17 & -0.12 \\
\hline & 0.18 & 0.18 & 0.18 & 0.18 & 0.18 \\
\hline \multirow[t]{2}{*}{$d_{i j}$} & $-0.08^{* * *}$ & $-0.08^{* * *}$ & $-0.08^{* * *}$ & $-0.08^{* * *}$ & $-0.08^{* * *}$ \\
\hline & 0.00 & 0.00 & 0.00 & 0.00 & 0.00 \\
\hline \multirow[t]{2}{*}{ Intercept } & $-32.99^{* * *}$ & $-32.37^{* * *}$ & $-32.44^{* * *}$ & $-32.77^{* * *}$ & $35.30^{* * * *}$ \\
\hline & 8.15 & 8.05 & 8.04 & 7.89 & 7.89 \\
\hline $\begin{array}{l}\text { Fixed effects } \\
\quad \text { (departments) }\end{array}$ & Yes & Yes & Yes & Yes & Yes \\
\hline $\mathrm{R}^{2}$ & 0.35 & 0.35 & 0.35 & 0.35 & 0.35 \\
\hline Obs. & 8398 & 8398 & 8398 & 8398 & 8398 \\
\hline
\end{tabular}

Notes: Robust standard errors appear under the coefficients.

*** Significant at $1 \%$.

** Significant at $5 \%$.

* Significant at $10 \%$

\section{Import equations}

\subsection{Traditional variables for interfirm trade}

To analyze imports, we work at the county level (departments). We first use OLS, then PPML. The GDP per capita again has a positive effect (Table 6). Real appreciation of the euro leads to increased imports, especially in aircrafts and engines, whereas the relative price has no effect on equipment imports. In addition, the estimates provide standard results for the distance variable, with significant negative coefficients, and the oil price effect is not significant.

When we account for the zero flows (Table 7), the coefficient of real exchange rates differs from zero in only one case, for equipment imports. The coefficient of oil price remains non-significant, and the coefficients of distance and air transport preserve the same signs but are higher in absolute value.

\subsection{FDI, contracts, and exchange rate}

The export data do not present any particularity, but the database of regional imports is more accurate, because we have information about not only imports but also arrivals. That is, customs services define as an import all products that come from a country outside the European Community (EC), whereas arrivals refer to products exchanged within the EC. This database also provides the country of origin, which allows us to distinguish several cases:

1. Imports of goods produced in the RoW, such as a product built in the United States and directly imported into a French region.

2. Arrival of goods produced in the RoW, such as a product built in the United States, imported into the Netherlands, and then exported to Ile de France, which represents an arrival from the United States.

3. Import of goods produced in the EC, such as a product built in Spain, outsourced in China, and then imported by a French region.

4. Arrival of goods produced in the EC, such as a product built in Spain and directly imported by a French region.

5. Import of goods produced in France, such as a product built in Ile de France, improved in the United States, and imported into MidiPyrénées.

6. Arrival of goods produced in France, such as a product built in Ile de France, improved in Germany, and imported into Midi-Pyrénées.

We cannot follow all travel by the product or the value added by each partner, but whether flows enter France as arrivals or imports represents precious information regarding the international fragmentation of the supply chain. Some flows, such as French arrivals or French imports, include intra-firm trade and outsourcing in partners' countries, first produced in France, improved abroad or in European countries, and then re-imported into France.

In comparison with the previous analysis, we introduce FDI in the aeronautic sector, denoted $f d i_{j t}$, a variable that fits quite well with O-ring theory. Eq. (3) establishes the importance of capital in $i$ and $j$ as a source of complementarities in the supply chain. We use OECD data, which provide inward and outward flows, to control for impact of the exit and entry of capital on French regions' imports.

In addition, we consider contracts between partners. Incomplete contracts are at the heart of the difficulties associated with explaining partner selection for outsourced production. Prior literature in international economics is prolific on this topic; contractual frictions clearly affect both location choices and trade (Acemoglu et al., 2007; Costinot, 2009; Levchenko, 2007; Nunn, 2007). Countries with good contractual institutions also enjoy a comparative advantage in the trade of contract-intensive goods. As a proxy for the contractual environment, we follow Nunn (2007) and Defever and Toubal (2007) and use the "rule of law" variable from the Governance Matters database (Kaufmann et al., 2009). This variable, which we denote $c_{j t}$, is based on 
Table 7

Import equation: PPML.

\begin{tabular}{|c|c|c|c|c|c|}
\hline & \multirow{2}{*}{$\begin{array}{l}\text { Nominal } \\
\text { exchange } \\
\text { rate }\end{array}$} & \multicolumn{4}{|c|}{ Real exchange rate } \\
\hline & & Aeronautic & Aircraft & Engine & Equipment \\
\hline \multirow[t]{2}{*}{$y_{i}$} & 1.01 & $1.42^{* * *}$ & $1.46^{* * *}$ & $1.33^{* * *}$ & -0.47 \\
\hline & 0.77 & 0.49 & 0.50 & 0.48 & 0.71 \\
\hline \multirow[t]{2}{*}{$y_{j}$} & $0.11^{*}$ & $0.11^{*}$ & $0.12^{*}$ & $0.11^{*}$ & $0.12^{*}$ \\
\hline & 0.07 & 0.07 & 0.07 & 0.07 & 0.07 \\
\hline \multirow[t]{2}{*}{$e_{t}$} & 0.58 & -0.45 & -0.54 & -0.34 & $3.05^{* * *}$ \\
\hline & 1.11 & 0.57 & 0.57 & 0.43 & 0.90 \\
\hline \multirow[t]{2}{*}{$m_{j}$} & $-0.25^{* * *}$ & $-0.25^{* * *}$ & $-0.25^{* * *}$ & $-0.25^{* * *}$ & $-0.24^{* * *}$ \\
\hline & 0.04 & 0.04 & 0.04 & 0.04 & 0.04 \\
\hline \multirow[t]{2}{*}{$a_{j}$} & $1.94^{* * *}$ & $1.93^{* * *}$ & $1.93^{* * *}$ & $1.93^{\text {*** }}$ & $1.93^{* * *}$ \\
\hline & 0.08 & 0.08 & 0.08 & 0.08 & 0.08 \\
\hline \multirow[t]{2}{*}{$o_{t}$} & 0.20 & 0.23 & 0.22 & 0.23 & -0.18 \\
\hline & 0.20 & 0.20 & 0.19 & 0.20 & 0.20 \\
\hline \multirow[t]{2}{*}{$d_{i j}$} & $-1.06^{* * *}$ & $-1.06^{* * *}$ & $-1.06^{* * *}$ & $-1.06^{* * *}$ & $-1.06^{* * *}$ \\
\hline & 0.04 & 0.04 & 0.04 & 0.04 & 0.03 \\
\hline \multirow[t]{2}{*}{ Intercept } & $-26.82^{* * *}$ & $-28.04^{* * *}$ & $-28.24^{* * *}$ & $-27.04^{* * *}$ & -9.54 \\
\hline & 8.28 & 7.64 & 7.62 & 7.83 & 9.27 \\
\hline $\begin{array}{l}\text { Fixed effects } \\
\text { (departments) }\end{array}$ & Yes & Yes & Yes & Yes & Yes \\
\hline $\mathrm{R}^{2}$ & 0.88 & 0.88 & 0.88 & 0.88 & 0.88 \\
\hline Obs & 88,990 & 88,990 & 88,990 & 88,990 & 88,990 \\
\hline
\end{tabular}

Notes: Robust standard errors appear under the coefficients.

$* * *$ Significant at $1 \%$.

* Significant at $10 \%$.

Table 8

FDI and contract environment.

\begin{tabular}{lll}
\hline Variable & Name & Source \\
\hline$c_{j t}$ & Contract environment & Governance matters database \\
$f d i_{j t}$ & Inward flows, outward flows & OECD database \\
\hline
\end{tabular}

surveys of businesspeople and polls of experts, and it measures perceptions of the effectiveness and enforceability of contracts.

To analyze the relevance of FDI, the contract environment, and the exchange rate on trade, we propose to fully exploit flows exiting France and/or the EC and then entering French regions as imports or arrivals. We use OLS without fixed effects, out of consideration of the size of the sample, which decreases substantially at this desegregated level of trade. In addition, to check the robustness of our analysis, we adopted a logit model, in which we could use all the data available (see also Helpman et al., 2008). We successively estimate the probability of importing each kind of flows. More precisely, we use the following equation:

$\operatorname{Prob}_{k j t}=\beta_{1} y_{i}+\beta_{2} y_{j}+\beta_{3} d_{i j}+\beta_{4} e_{t}+\beta_{5} c_{j t}+\beta_{6} f d i_{j t}+\varepsilon_{k j t}$,

where $k=$ EC imports, EC arrivals, RoW imports, RoW arrivals, France imports, or France arrivals.

Table 9 contains the OLS and logit results, using inward FDI and outward FDI separately (to reduce the potential for collinearity bias). In each case, the dependant variable takes a value of 1 for EC imports, whereas all other flows take a value of 0 . As these findings show, the exchange rate has a negative impact on imports but a positive effect on arrivals in European flows in three of the four specifications. Furthermore, inward FDI in the aeronautic sector indicates no impact on EC imports, though the European outward flow negatively affects the probability of imports from these countries. The results are the same for arrivals. A good contractual environment does not affect imports (cf. negatively with OLS and inward FDI) but reveals a positive impact on arrivals. Thus, in the European community, contract efficiency remains important, whereas RoW exchanges in the aeronautic sector do not seem determined by contractual institutions. The entire output could be destroyed by the malfunction of a simple component, which may explain why even a good contract environment in the RoW is not enough to ensure confidence in the longer production chain, which may be more fragile and prone to failure (Levine, 2012).

In Table 10 we present the results for arrivals and imports of French products-that is, products built in France, improved in a foreign country, and then imported into a French region. We depart from the standard gravity equation by not considering exporter GDP, which would be redundant, or distance, which equals 0 for all flows.

The coefficients of exchange rate again are negative, indicating that an appreciation of the euro increases the difficulty of exporting products of French origin, as well as the difficulty of reimporting these products after improvement. Outward FDI has a positive effect on the probability of importing products of French origin. This result may illustrate firms' reorganization trends: FDI from France to EC or the RoW increases imports.

Table 9

Imports and arrivals of European products.

\begin{tabular}{|c|c|c|c|c|c|c|c|c|}
\hline & \multicolumn{4}{|l|}{ Imports EC } & \multicolumn{4}{|l|}{ Arrivals EC } \\
\hline & \multicolumn{2}{|l|}{ Inward FDI } & \multicolumn{2}{|c|}{ Outward FDI } & \multicolumn{2}{|l|}{ Inward FDI } & \multicolumn{2}{|c|}{ Outward FDI } \\
\hline & OLS (FE) & Logit & OLS (FE) & Logit & OLS (FE) & Logit & OLS (FE) & Logit \\
\hline \multirow[t]{2}{*}{$y_{i}$} & 1.96 & $0.05^{* * *}$ & 3.08 & $0.04^{* * *}$ & $5.63^{* * *}$ & $-0.01^{* *}$ & $7.49^{* * * *}$ & $-0.01^{* *}$ \\
\hline & 1.49 & 0.00 & 1.95 & 0.00 & 1.13 & 0.005 & 1.04 & 0.006 \\
\hline \multirow[t]{2}{*}{$y_{j}$} & 1.53 & $0.001^{* * *}$ & -5.51 & 0.001 & $5.04^{* * *}$ & $0.007^{* * *}$ & $-15.37^{* *}$ & $0.004^{* * *}$ \\
\hline & 1.36 & 0.00 & 9.99 & 0.00 & 0.71 & 0.00 & 4.6 & 0.00 \\
\hline \multirow[t]{2}{*}{$d_{i j}$} & -1.99 & $-0.75^{* * *}$ & -11.25 & $-0.79^{* * *}$ & -0.48 & -0.55 & $-17.26^{* * *}$ & $-0.74^{* * *}$ \\
\hline & 1.7 & 0.16 & 14.4 & 0.15 & 0.80 & 0.00 & 4.40 & 0.11 \\
\hline \multirow[t]{2}{*}{$e_{t}$} & -11.98 & $-3.72^{* * *}$ & -8.41 & $-5.40^{* * *}$ & $-15.6^{* * *}$ & $2.72^{* * *}$ & 11.02 & $1.43^{* *}$ \\
\hline & 9.7 & 1.02 & 20.43 & 1.05 & 4.92 & 0.64 & 7.82 & 0.68 \\
\hline \multirow[t]{2}{*}{$c_{j t}$} & $-2.17^{* *}$ & -0.01 & 1.88 & 0.22 & $2.25^{* * *}$ & $0.36^{* * *}$ & $14.04^{* * *}$ & $0.57^{* * *}$ \\
\hline & 1.11 & 0.18 & 7.38 & 0.20 & 0.55 & 0.10 & 4.26 & 0.12 \\
\hline \multirow[t]{2}{*}{$f d i_{j t}$} & 0.20 & -0.15 & 0.35 & $-0.45^{* *}$ & 0.10 & -0.24 & -0.33 & $-0.42^{* * *}$ \\
\hline & 0.25 & 0.12 & 0.41 & 0.19 & 0.12 & 0.07 & 0.21 & 0.15 \\
\hline \multirow[t]{2}{*}{ Intercept } & 72.04 & 1.29 & 114 & & 49.49 & $-3.59^{* * *}$ & 48.4 & -2.15 \\
\hline & 57.98 & 1.25 & 85 & & 30.84 & 0.8 & 37.2 & 0.8 \\
\hline $\mathrm{R}^{2}$ & 0.14 & 0.12 & 0.21 & 0.11 & 0.39 & 0.15 & 0.31 & 0.18 \\
\hline Obs. & 54 & $\begin{array}{r}2091 \\
66 * * *\end{array}$ & 37 & $\begin{array}{r}2091 \\
72^{* * *}\end{array}$ & 171 & $\begin{array}{r}2091 \\
112^{* * *}\end{array}$ & 122 & $\begin{array}{r}2091 \\
247^{* * * *}\end{array}$ \\
\hline
\end{tabular}

Notes: Robust standard errors appear under the coefficients. $\mathrm{FE}=$ fixed effects.

$* * *$ Significant at $1 \%$.

** Significant at $5 \%$ 
Table 10

Imports and arrivals of French products.

\begin{tabular}{|c|c|c|c|c|c|c|c|c|}
\hline & \multicolumn{4}{|c|}{ Imports RoW } & \multicolumn{4}{|l|}{ Arrivals RoW } \\
\hline & \multicolumn{2}{|l|}{ Inward FDI } & \multicolumn{2}{|c|}{ Outward FDI } & \multicolumn{2}{|l|}{ Inward FDI } & \multicolumn{2}{|c|}{ Outward FDI } \\
\hline & OLS & Logit & OLS & Logit & OLS & Logit & OLS & Logit \\
\hline \multirow[t]{2}{*}{$y_{i}$} & $10.51^{* * *}$ & -0.01 & $10.13^{* * *}$ & 0.01 & $10.07^{* * *}$ & -0.01 & $9.91^{* *}$ & 0.01 \\
\hline & 2.27 & 0.01 & 2.04 & 0.01 & 2.63 & 0.01 & 2.55 & 0.01 \\
\hline \multirow[t]{2}{*}{$e_{t}$} & $-18.76^{* *}$ & -1.57 & $-18.8^{* *}$ & -1.66 & $-21.06^{* *}$ & -2.61 & $-20.3^{* *}$ & $-3.11^{*}$ \\
\hline & 8.8 & 1.29 & 7.71 & 1.37 & 10.4 & 1.7 & 9.9 & 1.83 \\
\hline \multirow[t]{2}{*}{$c_{j t}$} & -12.19 & $0.6^{* * *}$ & -3.8 & 0.23 & 7.8 & $0.59^{* * *}$ & -1.45 & 0.21 \\
\hline & 13.8 & 0.2 & 15.47 & 0.24 & 16.5 & 0.21 & 19 & 0.25 \\
\hline \multirow[t]{2}{*}{$f d i_{j t}$} & 0.06 & 0.05 & 0.38 & $0.46^{* * *}$ & -0.05 & 0.11 & -0.39 & $0.50^{* * *}$ \\
\hline & 0.76 & 0.09 & 0.75 & 0.07 & -0.06 & 0.09 & 0.92 & 0.07 \\
\hline \multirow[t]{2}{*}{ Intercept } & 124 & -1.37 & 114 & -0.83 & $112^{* *}$ & 15.24 & $121^{* *}$ & 19.16 \\
\hline & 53 & 1.53 & 40 & 1.61 & 62 & 12.03 & 52 & 12.8 \\
\hline $\mathrm{R}^{2}$ & 0.27 & 0.02 & 0.28 & 0.04 & 0.21 & 0.02 & 0.19 & 0.05 \\
\hline Obs used & 65 & 2091 & 75 & 2091 & 62 & 2091 & 72 & 2091 \\
\hline Wald stat. & & $14.7^{* * *}$ & & $40^{* * *}$ & & $16^{* * *}$ & & $49^{* * *}$ \\
\hline
\end{tabular}

Notes: Robust standard errors appear under the coefficients.

*** Significant at $1 \%$.

** Significant at $5 \%$.

* Significant at $10 \%$.

\section{Conclusion}

In this article, we have sought to explain France's aeronautic trade over the period 2003-2010. To do so, we studied exports and imports out of and into different French regions. The choice to study regional trade appears justified by France's own political and economic decisions to establish three aerospace/aeronautic industry clusters. In addition, geographical locations of firms of this sector reflect political events, including the two world wars, as well as a heritage dating back to the beginning of aviation. Estimates of gravity models, using panel methods, thus can reveal the influence of different trade determinants. First, GDP per capita has the positive expected effects on exports and imports. Second, the appreciation of the euro has a negative impact on exports and a positive effect on imports, confirming the fears of European politicians and managers of the aeronautic sector. Third, distance consistently has a negative impact on trade, but military spending favors exchanges of aeronautic products. Fourth, we distinguish French imports and arrivals, as well as products manufactured in Europe and in France. With supplementary estimations (Table 8), we show that outward FDI affects imports and arrivals of European products negatively but affects imports and arrivals of French products positively. Across all the models we derived, we obtained a negative effect of the appreciation of the euro on trade, reflecting the ongoing difficulties associated with exporting goods produced in the euro area.

\section{References}

Acemoglu, D., Antràs, P., Helpman, E., 2007. Contracts and technology adoption. Am. Econ. Rev. 97 (3), 916-943.

Anderson, J.E., 2011. The gravity model. Annu. Rev. Econ. 3, 133-160.

Anderson, J.E., van Wincoop, E., 2003. Gravity with gravitas: a solution to the border puzzle. Am. Econ. Rev. 93, 170-192.

Anderson, J.E., Vesselovsky, M., Yotov, Y., 2014. "Gravity with Scale Economies", Drexel U. WP 4.

Apter, J., 2010. French Aerospace Awaits 2011 Recovery. http://www.ainonline.com (July 21).
Baldwin, R., 2006. Globalisation: The Great Unbundling(s). Economic Council of Finland. Bénassy-Quéré, A., Fontagné, L., Raff, H., 2011. Exchange-rate misalignments in duopoly: the case of Airbus and Boeing. World Econ. 623-641.

Brülhart, M., Trionfetti, F., 2009. A test of trade theories when expenditure is home biased. Eur. Econ. Rev. 53 (7), 830-845 (October).

Buat, A., 2012. La Filière Aéronautique et Spatiale, un Domaine D'Excellence Francilien. Rapport CESER Ile de France.

Candau, F., Dienesch, E., 2011. A Survey on the Micro-Foundation of the Trade Gravity Equation. SSRN WP.

Costinot, A., 2009. On the origins of comparative advantage. J. Int. Econ. 77 (2), 255-264.

Defever, F., Toubal, F., 2007. Productivity and the sourcing modes of multinational firms: evidence from french firm-level data. CEP Discussion Paper No. 842.

ECORYS, 2009. Study on the competitiveness of the EU security industry, ENTR/06/054. Final Report, Brussels (November. http://ec.europa.eu/enterprise/policies/security/ files/study_on_the_competitiveness_of_the_eu_security_industry_en.pdf).

Grossman, G., Rossi-Hansberg, E., 2012. Task trade between similar countries. Econometrica 80 (2), 593-629.

Head, K., Mayer, T., 2011. Gravity, market potential and development. J. Econ. Geogr. 11 (2), 281-294

Helpman, E., Melitz, M.J., Rubinstein, Y., 2008. Estimating trade flows: trading partners and trading volumes. Q. J. Econ. 123, 441-487.

Kaufmann, D., Kraay, A., Mastruzzi, M., 2009. Governance matters VIII, aggregate and individual governance indicators. The World Bank Development Research Group, Policy Research Working Paper 4978.

Kremer, M., 1993. The O-ring theory of economic development. Q. J. Econ. 108 (3), 551-575.

Levchenko, A., 2007. Institutional quality and international trade. Rev. Econ. Stud. 74 (3), 791-819.

Levine, D.K., 2012. Production chains. Rev. Econ. Dyn. 15 (3), 271-282.

Mirza, D., Nicoletti, G., 2004. What is so special about trade in services? U. Nottingham Working Paper No. 2.

Nunn, N., 2007. Relationship specificity, incomplete contracts and the pattern of trade. Q. J. Econ. 122 (2), 569-600.

Santos Silva, S.J., Tenreyro, S., 2006. The log of gravity. Rev. Econ. Stat. 88, 641-658.

Santos Silva, S.J., Tenreyro, S., 2009. Further simulation evidence on the performance of the Poisson pseudo-maximum likelihood estimator. Economics Discussion Papers 666. University of Essex, Department of Economics.

Schönfeld, T., Jouaillec, F., 2008. The regional aerospace cluster policy in Europe. 26th International Congress of the Aeronautical Sciences (http://www.icas.org/ICAS_ARCHIVE_CD1998-2010/ICAS2008/PAPERS/628.PDF).

Zuliani, J.-M., Jalabert, G., 2005. L'Industrie Aéronautique Européenne: Organisation Industrielle et Fonctionnement en Réseaux. L'Espace Géogr. 34 (2), 117-144. 